\title{
Nyt civilsamfund i Afghanistan
}

\section{Malek Sitez}

\section{For fem år siden var civilsamfundet præget af stor mistillid, og det var umuligt for NGO'erne at være i stue sammen. I dag eksisterer der et netværk for civilsamfund og menneskerettigheder}

For fem år siden rejste min kollega Lisbeth Arne Pedersen og jeg til Afghanistan på en første mission for Institut (dengang Center) for Menneskerettigheder (IMR). Vi foretog yderligere to missioner sammen, og en lang række andre medarbejdere fra IMR har siden medvirket - og medvirker - til at støtte opbygningen af et civilsamfund, som arbejder ud fra internationale menneskerettighedsværdier. Der er nået rigtig meget på de fem år.

Da vi kom, var der kun få organisationer i Kabul, som beskæftigede sig med menneskerettigheder, demokratisering og styrkelse af civilsamfundet. På det tidspunkt var de baseret i nabolande som Pakistan, i Centralasien og Indien, men deres repræsentanter Kabul blev i stigende grad involveret i deres arbejde. Der var dog nogle, som opererede i
Afghanistan, fx All Afghan Women's Union, Cooperation Centre for Afghanistan, Association for Defense of the Rights of Writers, Afghan Women's Network, Danish Committee for Aid to Afghan Refugees (DACAAR), Den Danske Afghanistan-Komité, den schweiziske SwissPeace og Association of Afghan Lawyers.

Situationen var alt andet end stabil. Det var svært at forstille sig, at talebanerne var væk, og truslen om deres tilbagekomst var i høj grad real. Blandt magthaverne herskede der uro, og den skæve magtfordeling påvirkede også NGO'erne. De havde også svært ved at vinde hinandens tillid - det kunne ligefrem være farligt - på grund af deres meget forskellige politiske, ideologiske, religiøse, etniske, sproglige og kulturelle baggrund. Året 2002 var præget af stor mistillid inden for civilsamfundet i Afghanistan. 
I begyndelsen af 2003 begyndte det internationale samfund at tillægge NGO'erne mere vægt. Samarbejde med civilsamfundet indgik som en vigtig del af donorernes strategi i Afghanistan. Der var også blevet afholdt en parallel civilsamfundskonference under Bonn-konferencen i Tyskland.

\section{Civilsamfundets rolle}

Fra 2002 til 2004 har IMR gennemført fire missioner til Afghanistan. Efter den første undersøgende mission i 2002 organiserede IMR i 2003 en national workshop for All Afghan Women's Union (AAWU). Denne workshop gav AAWU og IMR mulighed for at lære hinanden at kende, ligesom det gav anledning til drøftelser af mulighederne for at styrke civilsamfundet og dets arbejde med menneskerettigheder i Afghanistan.

Drøftelserne omfattede diskussioner af begreberne demokrati, menneskerettigheder og civilsamfund og ikke mindst kvindernes rolle i samfundet. Ud fra denne konceptuelle diskussion blev det drøftet, hvad civilsamfundets rolle bør være i denne sammenhæng, og hvilken støtte det kræver at udfylde denne rolle.

I den forbindelse skal det bemærkes, at civilsamfundet - og befolkningen - godt nok havde hørt om demokrati, menneskerettigheder og civilsamfund, men drøftelserne viste, at det egentlige kendskab til indholdet og konsekvenserne af disse begreber var meget beskedent.

Herefter organiserede IMR sammen med AAWU en brainstorming for NGO'er, menneskerettighedsaktivister, journalister m.fl. Denne brainstorming resulterede - ved konsensus - i en anmodning til IMR om at organisere en paraply for menneskerettigheds-NGO'er i Afghanistan for at styrke disse organisationers arbejde og koordination og samarbejde mellem dem.

2004 opnåede IMR støtte fra Danida til at fortsætte arbejdet i Afghanistan, og i august 2004 bistod IMR ved oprettelsen af Civil Society $\mathcal{E} \mathrm{Hu}$ man Rights Network (CSHRN), som startede med 25 medlemmer. I dette netværk var arbejdet koncentreret om organisationer i Kabul med fokus på opbygningen af netværket og dets medlemmers kapacitet både institutionelt og på menneskerettighedsområdet. Desuden indledte netværket tidligt en aktiv dialog med statslige myndigheder.

Der blev fx afholdt to møder med præsident Karzai om samarbejdet mellem stat og civilsamfund. Netværket har også organiseret en række seminarer for forskellige afdelinger i Justitsministeriet, for anklagemyndigheder, Højesteret og politiet vedrørende menneskerettigheder. Desuden blev netværket involveret i programmet vedrørende 'Transitional Justice'. Der blev afholdt en national konference med 76 deltagere fra 26 provinser om 'Transitional Justice', og der blev etableret et ufor- 
malt netværk af civilsamfundsorganistioner på dette område.

En workshop i Kabul med deltagere fra hele landet om Retten til Oplysning blev en stor succes. Den blev organiseret af CSHRN og IMR i fællesskab, og der var deltagelse både fra civilsamfundet, det afghanske parlament og regeringen. Et af resultaterne var etablering af en konstruktiv relation mellem CSHRN og det afghanske parlament om retten til oplysning. Det har også vist sig, at den nyligt vedtagne lovgivning vedrørende medierne er blevet betydeligt forbedret blandt andet ved en indsats fra CSHRN.

I 2003 var det reelt umuligt for NGO'erne at være i stue sammen, men i dag er CSHRN vokset til 58 medlemmer, og der er etableret en god dialog og et konstruktivt samarbejde. CSHRN har etableret en afdeling for menneskerettighedsuddannelse med 40 trænere fra Kabul og forskellige regioner. I juni 2007 afholdt CSHRN også en sommerskole i Kabul for alle trænerne, hvor eksperter fra IMR bidrog til undervisningen. Trænerne fungerer både i Kabul og provinserne med udgangspunkt i de værdier, som sommerskolen byggede på.

\section{Åben debat}

\section{2005 offentliggjorde CSHRN den} første professionelle undervisningshåndbog $\mathrm{om}$ menneskerettigheder $\mathrm{i}$ Afghanistan. Den bliver i dag an- vendt af NGO'er, Afghan Independent Human Rights Commission, den afghanske menneskeretttighedskommission, og en række statslige myndigheder - fx Kvindeministeriet, Justitsministeriet og Indenrigsministeriet. Netværket arbejder nu på endnu en håndbog om kvinders rettigheder.

CSHRN udgiver også en række publikationer: et debatblad om menneskerettigheder på akademisk niveau rettet mod NGO'er, universiteter og skoler. CSHRN har også udgivet en bog på Afghanistans nationalsprog, som forklarer/fortolker den terminologi, der anvendes inden for menneskerettighederne, internationale menneskerettighedsinstrumenter, brochurer og nyhedsbreve.

I august 2004 lancerede CSHRN en menneskerettighedsradio. Hver fredag i den bedste sendetid kan alle afghanere høre programmet 'Stemmen'. Nogle af de første programmer handlede om civilsamfundets rolle i landets demokratisering, stemmeret og kvinders rettigheder.

Det første program var en rundbordsdiskussion om menneskerettighedsproblemer i Afghanistan.

Det lyder måske ikke af meget i en dansk sammenhæng. Men i Afghanistan er der ingen tradition for at tale åbent om statens rolle i forhold til samfundets problemer. Reaktionen var overvældende - folk havde aldrig før hørt en åben dialog mellem staten og civilsamfundet. Deres 
reaktion var, at nu havde de fået deres egen stemme.

Deltagerne i diskussionen var bl.a. en repræsentant fra Afghanistans Menneskerettighedskommission, en fremtrædende forfatter og forkæmper for menneskerettighederne samt en embedsmand fra Afghanistans Informations- og Kulturministerium. Formålet med 'Stemmen' er at udbrede kendskab til og forståelse for de grundlæggende menneskerettigheder til alle afghanere. Gennem 25 år har afghanerne levet med krig, borgerkrig, etniske konflikter og senest Taleban-styret, der blev væltet i 2001. I 25 år har afghanerne oplevet massive menneskeretskrænkelser, begået i forskellige politiske ideologiers navn.

'Stemmen' er i dag blevet en interessant platform for debatten om menneskerettighederne i Afghanistan. Et stort antal parlamentsmedlemmer, civilsamfundsorganisationer, regeringsrepræsentanter og menneskerettighedsaktivister har deltaget i programmerne

I august 2006 begyndte CSHRN anden fase af netværkets arbejde. Swiss Agency for Development and Cooperation (SDC) blev CSHRN's anden donor sammen med Danida. CSHRN har vedtaget en langsigtet strategi med fokus på tre kerneområder:

- Kapacitetsopbygning, både institutionelt og tematisk.

- Koordination af civilsamfundets aktiviteter.
- Fortalervirksomhed.

I dag har CSHRN hovedkontor og et velfungerende sekretariat i Kabul, og tre mobile regionale koordineringscentre i tre strategisk valgte byer: Mazar-e-Sharif som dækker ni provinser i det nordlige Afghanistan, i Herat som dækker fire provinser vest på og Nangarhaar som dækker fire provinser øst på. Fra Kabul arbejder netværket med fem provinser i det centrale Afghanistan. CSHRN har etableret et meget tæet samarbejde med AIHRC, hvor de to institutioner supplerer hinanden i forbindelse med kapacitetsopbygning og oplysning/undervisning om menneskerettighederne.

\section{Fortsat mange opgaver}

Civilsamfundet i Afghanistan bliver stadig bedre organiseret. De er aktive vedrørende demokratisering og reformer i retssektoren. Der forgår nu en konstant dialog mellem civilsamfundet, det internationale samfund og den afghanske stat. CSHRN har også åbnet et 'Mini Ressource Center' med et lille bibliotek med omkring 500 titler, tre computere med internetadgang og læsesal. På centret afholdes tillige debatter med videre i konferencesalen.

Forholdet mellem staten og civilsamfundet er blevet væsentligt bedre. For fem år siden agerede staten og civilsamfund som gensidige fjender og i skarp opposition, hvorimod kommunikationen mellem de to slet 
ikke er ringe i dag. Der er stadigvæk masser arbejde at gøre og masser af opgaver, der skal udføres. Regionerne er stadigvæk præget af lokale krigsherrer, som påvirker på NGO'erne og deres aktiviteter. Ikke overraskende er det især menneskerettigheds-NGO'er der er under pres. Sidst jeg var i Samangaan og Baghlaan provinserne for at medvirke ved workshops for de lokale NGO'er, oplevede jeg, hvor krævende arbejdet er. Begreber som demokrati, menneskerettigheder og retsstat skal forklares meget grundigt og i et sprog, som folk kan forstå og relatere sig til. Der er stor interesse og entusiasme i provinserne, men desværre er der nærmest ingen muligheder for at arbejde der. På denne baggrund har CSHRN i april oprettet Mobile Working Groups (MWG, mobile arbejdsgrupper), som - i det omfang det er muligt - rejser rundt til de forskellige provinser for at hjælpe og styrke de lokale menneskerettigheds-NGO'er.

IMR og CSHRN har etableret et tæt, løbende samarbejde. Forskellige eksperter og undertegnede som projektleder rejser meget ofte til Kabul og så vidt muligt til provinserne for at støtte og rådgive vores afghanske partner. Både IMR og CSHRN håber, at sikkerhedssituationen i samarbejdets tredje fase, som påbegyndes næste år, vil tillade endnu større fokus på provinserne.

Malek Sitez er projektleder på Institut for Menneskerettigheder med ansvar for arbejdet $i$ Afghanistan, som han besøger flere gange om året, senest $i$ april - maj 2007 